UDC 613.26:616-037:615.9:612.014.46

https://doi.org/10.26641/2307-0404.2020.4.221663

\author{
O.P. Vavrinevych ${ }^{1}$, \\ B.I.Shpak ${ }^{3}$, \\ A.M. Antonenko ${ }^{1}$, \\ S.T. Omelchuk ${ }^{2}$, \\ T.I. Zinchenko ${ }^{i}$
}

\title{
HYGIENIC SUBSTANTIATION OF CALCULATING MODELS FOR PROGNOSIS OF TOXICITY OF DIFFERENT CLASSES INSECTICIDES (SECOND PART)
}

Bogomolets National Medical University Department Hygiene and Ecology No. $1^{1}$ Institute of Hygiene and Ecology of Bogomolets National Medical University ${ }^{2}$ Peremohy av., 34, Kyiv, 03057, Ukraine «Syngenta» LCC ${ }^{3}$, Kozatska str., 120/4, Kyiv, 02000, Ukraine Національний медичний університет ім. О.О. Богомольия Кафедра гігієни та екології № $1^{l}$

(зав. - член-кор. НАМН України, д. мед. н., проф. В.Г. Бардов) Інститут гігієни та екології Національного медичного університету ім. О.О. Богомольия ${ }^{2}$ пр. Перемоги, 34, Київ, 03057, Украӥна ООО «Сингента» вул. Козаиьька, 120/4, Київ, 02000, Украӥна ${ }^{3}$ e-mail: antonenko1985@ukr.net

Цитування: Медичні перспективи. 2020. T. 25, № 4. С. 166-173

Cited: Medicni perspektivi. 2020;25(4):166-173

Key words: insecticide, toxicology, calculation models, regression equations Ключові слова: інсектицид, токсикологія, розрахункові моделі, рівняння регресії Ключевые слова: инсектицид, токсикология, расчетные модели, уравнения регрессии

\begin{abstract}
Hygienic substantiation of calculating models for prognosis of toxicity of different classes insecticides (second part). Vavrinevych O.P., Shpak B.I., Antonenko A.M., Omelchuk S.T., Zinchenko T.I. This work is the second part of our study to develop alternative experimental mathematic models for predecting toxicity of insecticides, where we carried out a statistical analysis and comparative estimation of the toxicometric parameters obtained experimentally and calculated according to the proposed equations. In the first stage calculations were carried out and the most reliable models were proposed. The purpose of the research is the scientific substantiation and statistical analysis of the calculation models for predicting the toxicity of insecticides of different classes. For research we took the insecticides of the following chemical classes: neonicotinoids, pyrethroids, organophosphorus compounds. Statistical analysis of the linear and nonlinear regression equations obtained for insecticides was conducted. The equations described the dependence of subthreshold doses in the chronic experiment of all insecticides, the median lethal doses at oral admission of pyrithoids and neonicotinoids from molecular weight; and toxicometry parameters of all insecticides and their individual groups (pyrithoids, neonicotinoids, organophosphorus compounds) on melting temperature and the octanol-water partition coefficient. On the basis of a comparison of the toxicometry parameters obtained experimentally (actual parameters) and calculated according to the proposed equations checking of possibility of using of the calculating models for predicting the danger of the investigated groups of insecticides was performed. For substantiated pairs of resultant and factorial variables for pyrethroids, neonicotinoids, and organophosphorus pesticides a reliable correlation was established $\left(r_{\text {actucal }}>r_{\text {table }}\right.$ at $\left.p=0.05\right)$ or trend $\left(r_{\text {actucal }}>r_{\text {table }}\right.$ at $\left.p=0.1\right)$. A good and very good consistency of the features selected for the calculations according to the Cronbach's alpha (index ranged from 0.8 and above) was indicated. The developed algorithm makes it possible to significantly simplify the conduction of toxicological studies of the studied classes of insecticides.
\end{abstract}

Реферат. Гігіснічне обгрунтування розрахункових моделей прогнозування токсичності інсектицидів різних класів (друга частина). Вавріневич О.П., Шпак Б.І., Антоненко А.М., Омельчук С.Т., Зінченко Т.І. Ця робота є другою частиною нашого дослідження щзодо розробки альтернативних експериментальних математичних моделей прогнозування токсичності інсектицидів, де ми провели статистичний аналіз та порівняльну оцінку токсикометричних параметрів, отриманих експериментально та обчислених згідно із запропонованими рівняннями. На першому етапі були проведені розрахунки та запропоновані достовірні моделі. Метою дослідження було наукове обгрунтування та статистичний аналіз розрахункових моделей 
прогнозування токсичності інсектицидів різних класів. Для дослідження ми взяли обрані інсектицици таких хімічних класів: неонікотиноїди, піретроїди, фосфорорганічні сполуки. Ми провели статистичний аналіз лінійних та нелінійних рівнянь регресії, отриманих для інсектицидів. У рівняннях описано залежність підпорогових доз у хронічному експерименті всіх інсектицииді, середніх летальних доз при пероральному надходженні піритоїдів та неонікотиноїдів від молекулярної маси; параметрів токсикометрї всіх інсектициців та їх окремих груп (піритоїди, неонікотиноїди, фосфорорганічні сполуки) $i$ температури плавлення та коефіцієнту розподілу октанол-вода. На основі порівняння параметрів токсикометрії, отриманих експериментально (фактичні параметри), та розрахованих за запропонованими рівняннями здійснено перевірку можливості використання розрахункових моделей для прогнозування небезпеки досліджуваних груп інсектицидів. Для обтрунтованих пар результуючих та факторіальних змінних для піретроїдів, неонікотиноїдів та фосфорорганічних пестищидів було встановлено достовірну кореляцію. Виявлено добрий $і$ дуже добрий зв'язок характеристик, вибраних для розрахунків, за альфою Кронбаха (індекс коливався від 0,8 і вище). Розроблений алгоритм дозволяє значно спростити проведення токсикологічних досліджень інсектицидів досліджуваних класів.

This work is the continuation of our project on development of calculation models for toxicological assessment of pesticides in silico. Nowadays specialists of Hygiene and Ecology Institute of Bogomolets National Medical proposed calculating models for predicting fungicides and herbicides toxicity $[4,8,10]$. In the previous article we have proposed alternative experimental mathematic models for insecticides [5]. In the first stage, calculations will be carried out and the most reliable models will be proposed. And it is second part of our study on development of alternative experimental mathematic models for predicting insecticides toxicity.

Methods of mathematical modeling are in accordance with modern principles of bioethics. They are, in comparison with laboratory experiments, fast, labor-saving, cost-effective [3, 7, 9]. However, when developing such methods, care must be taken to evaluate their adequacy and the reliability of the possible results.

That is why we have subjected the calculated equations to a careful statistical analysis.

The purpose of the research was scientific substantiation and statistical analysis of the calculation models for predicting toxicity of insecticides of different classes.

\section{MATERIALS AND METHODS OF RESEARCH}

We conducted a statistical analysis of the linear and nonlinear regression equations obtained for insecticides [5].

The equation described the dependence of NO(A)EL in the chronic experiment of all insecticides, the median lethal doses at oral admission ( $\mathrm{LD}_{50}$ per os) of pyrithoids and neonicotinoids from molecular weight; toxicometry parameters of all insecticides and their individual groups (pyrithoids, neonicotinoids, organophosphorus compounds) on melting temperature and the octanol-water partition coefficient, $\log \mathrm{P}_{\mathrm{o} / \mathrm{w}}$.

Only those equations were used for further analysis which were adequate for Fisher's criterion, and the coefficients of its regression were reliable according to Student's criterion $(\mathrm{p}<0.05)$.

Statistical processing of the results was performed using the package of licensed statistical software IBM SPSS StatisticsBase v.22 and MS Excel (v. 14.0.4760.1000; license 02260-018-00001064863).

The standardized Cronbach's alpha coefficient $(\alpha)$ was calculated by the formula:

$$
\alpha_{s t}=\frac{N \cdot r}{1+(N-1) \cdot r}
$$

where $\mathrm{N}$ - the number of observation components; $\mathrm{r}$ - average correlation coefficient between components.

When the Cronbach's alpha coefficient is $\alpha_{\mathrm{st}}>0.9-$ consistency of characteristics is very good; $>0.8-$ consistency of characteristics is good; $>0.7-$ consistency of characteristics is acceptable; $>0.6-$ consistency of characteristics is questionable; $>0.5-$ consistency of characteristics is poor; $\leq 0.5-$ consistency of characteristics is not sufficient.

Cronbach's alpha may take values from $-\infty$ to 1 , but only positive values have been interpreted. If the coefficient takes the value 1 , then the test results are completely identical.

\section{RESULTS AND DISCUSSION}

Previously [5] the following significant correlations (at $\mathrm{p}<0.05$ ) have been established:

- with increasing molecular weight of pyrithoids and neonicotinoids values of NO(A)ELs in the chronic experiment of all insecticides and the median lethal doses at oral admission also increased:

- with increasing melting temperature and the octanol-water partition coefficient, $\log \mathrm{P}_{\mathrm{o} / \mathrm{w}}$ toxicometry parameters values of all insecticides and their individual groups (pyrithoids, neonicotinoids, organophosphorus compounds) decreased.

The checking of using possibility of the calculating models for predicting the danger of the 
investigated groups of insecticides was performed on the basis of a comparison of the parameters of toxicometry obtained experimentally (actual parameters) and the calculated according to the proposed equations (Fig. 1-4).

In most cases, the calculated values correlated with those established experimentally (Table). For the substantiated pairs of resultant and factorial variables for pyrethroids, neonicotinoids, and organophosphorus pesticides, a reliable correlation was established $\left(\mathrm{r}_{\text {actucal }}>\mathrm{r}_{\text {table }}\right.$ at $\left.\mathrm{p}=0.05\right)$ or trend $\left(\mathrm{r}_{\text {actucal }}>\mathrm{r}_{\text {table }}\right.$ at $\left.\mathrm{p}=0.1\right)$.
In addition, the internal consistency of the objectdescribing characteristics was evaluated using the Cronbach's alpha. For all the proposed equations, the value of this index ranged from 0.8 and above, which indicates a good and very good consistency of the features selected for the calculations.

In most cases, the calculated percutaneous $\mathrm{LD}_{50}$ indices were higher than previously established, but this is due to the fact that almost all experimentally established indices of these values are presented as "more than...". That is, they really could have been much higher.

\section{Relationship between experimentally established and estimated values of toxicological parameters}

\begin{tabular}{|c|c|c|c|c|c|c|c|c|c|}
\hline \multirow{4}{*}{ Chemical class } & \multirow{4}{*}{ Resulting variable } & \multirow{4}{*}{ Factorial variable } & \multicolumn{7}{|c|}{ Statistical parameters } \\
\hline & & & \multicolumn{4}{|c|}{ correlation coefficient } & \multirow{3}{*}{$\mathbf{n}$} & \multirow{2}{*}{\multicolumn{2}{|c|}{$\alpha_{s t}$}} \\
\hline & & & \multicolumn{2}{|c|}{$\mathbf{r}_{\text {actual }}$} & \multicolumn{2}{|c|}{$\mathbf{r}_{\text {tabl }}$ at $\mathbf{p}$} & & & \\
\hline & & & 1 & nl & 0,05 & 0,1 & & $\mathbf{l}$ & nl \\
\hline \multirow[t]{2}{*}{ Insecticides } & $\mathrm{LD}_{50}$ per cut, $\mathrm{mg} / \mathrm{kg}$ & $\begin{array}{c}\text { octanol-water partition } \\
\text { coefficient, } \log P_{0 / w}\end{array}$ & 0.005 & 0.209 & 0.334 & 0.283 & 35 & 0.3 & 7.2 \\
\hline & NO(A)EL, mg/kg & & 0.241 & 0.204 & 0.374 & 0.317 & 28 & 13.3 & 8.2 \\
\hline Pyre-throids & $\mathrm{LD}_{50}$ per os, $\mathrm{mg} / \mathrm{kg}$ & molecular weight & $0.501 * *$ & $0.589 *$ & 0.602 & 0.521 & 11 & 10.5 & 12.1 \\
\hline \multirow{2}{*}{$\begin{array}{l}\text { Oganophos- } \\
\text { phorus } \\
\text { compounds }\end{array}$} & NO(A)EL, mg/kg & melting temperature, ${ }^{\circ} \mathrm{C}$ & 0.744 & $0.938 *$ & 0.878 & 0.805 & 5 & 6.7 & 10.0 \\
\hline & $\mathrm{LC}_{50}$ inhal, $\mathrm{mg} / \mathrm{m}^{3}$ & & 0.757 & 0.721 & 0.878 & 0.805 & 5 & 6.8 & 7.8 \\
\hline $\begin{array}{l}\text { Neonico- } \\
\text { tinoids }\end{array}$ & $\mathrm{LD}_{50}$ per os, $\mathrm{mg} / \mathrm{kg}$ & molecular weight & $0.846 * *$ & $0.958 *$ & 0.878 & 0.805 & 5 & 7.6 & 11.1 \\
\hline
\end{tabular}

Notes: ${ }^{*}-$ the results are reliable at $\mathrm{p}<0.05 ;{ }^{*} *$ - trend, $0.05<\mathrm{p}<0.1 ; 1-$ linear; $\mathrm{nl}$ - non linear.

It should be noted that the correlations we obtained (Table) between the toxicity criteria of the investigated fungicides and their physicochemical properties, as confirmed by the inverse calculations (Fig. 1-4), are similar to those previously substantiated for neonicotinoid insececticides [1].

We also performed similar calculations for 3 compounds of derivatives of tetram and tetronic acids class (spiromesifen, spirodiclofen and spirotetramat); 3 benzoyl-ureas (diflubenzuron, navalurone, teflubenzuron); 4 compounds of the carbamates class (carbosulfan, methomyl, carbaryl, phenoxycarb); 2 avermectins (abamectin and emamectin benzoate) [6], but no reliable correlation of their toxicological parameters with physicochemical properties was found.

In the case of carbamates, this can be explained by the fact that the thresholds for their toxic effects were justified more than 30 years ago, often according to outdated approaches, on different species of animals (rodents, mammals). And probably when revaluating according to current approaches, we could get somewhat other values. For the rest of the classes mentioned, there is likely to be a problem in the small number of samples to study. Later, when more representatives of classes appear, the correlation analysis needs to be repeated. 


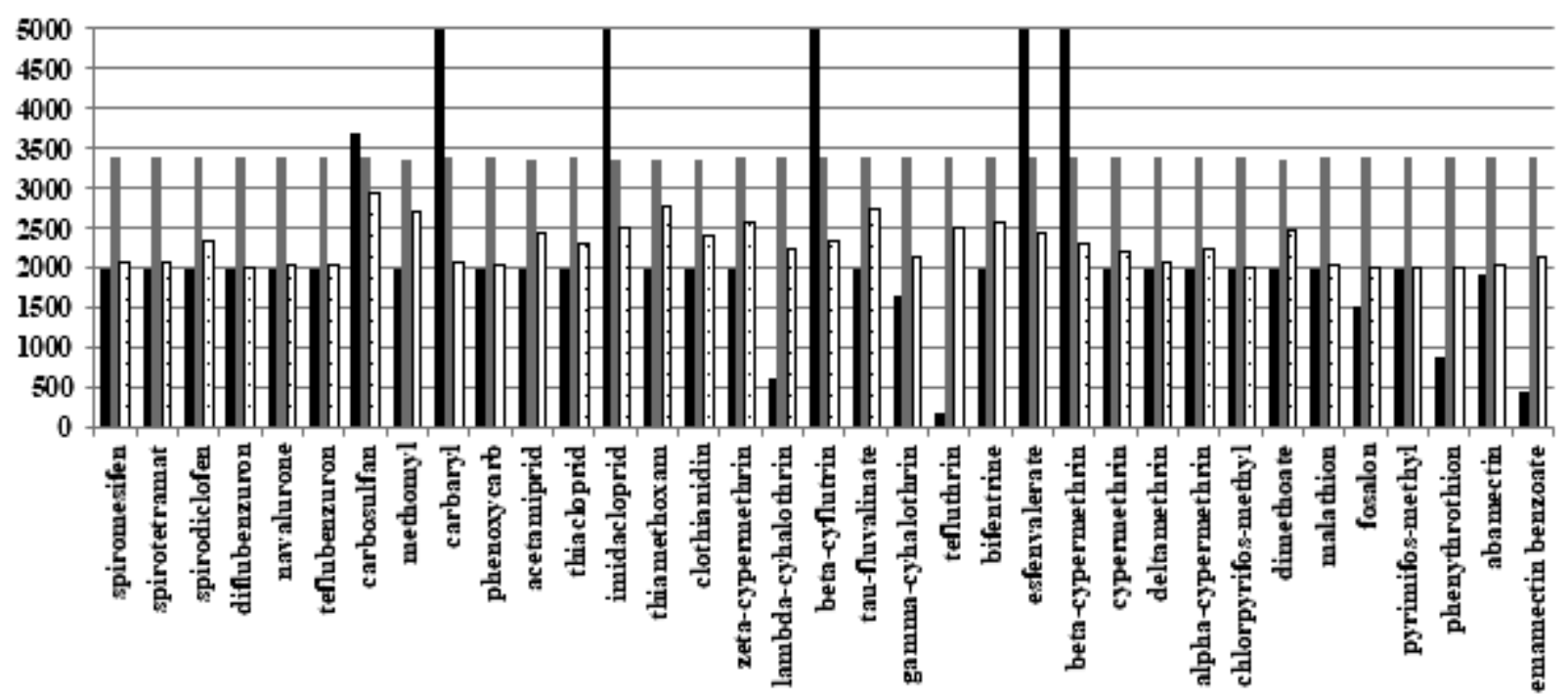

- actual indexes | indexes, calculated using linear regretion equations $\square$ indexes, calculated using nonlinear regretion equations

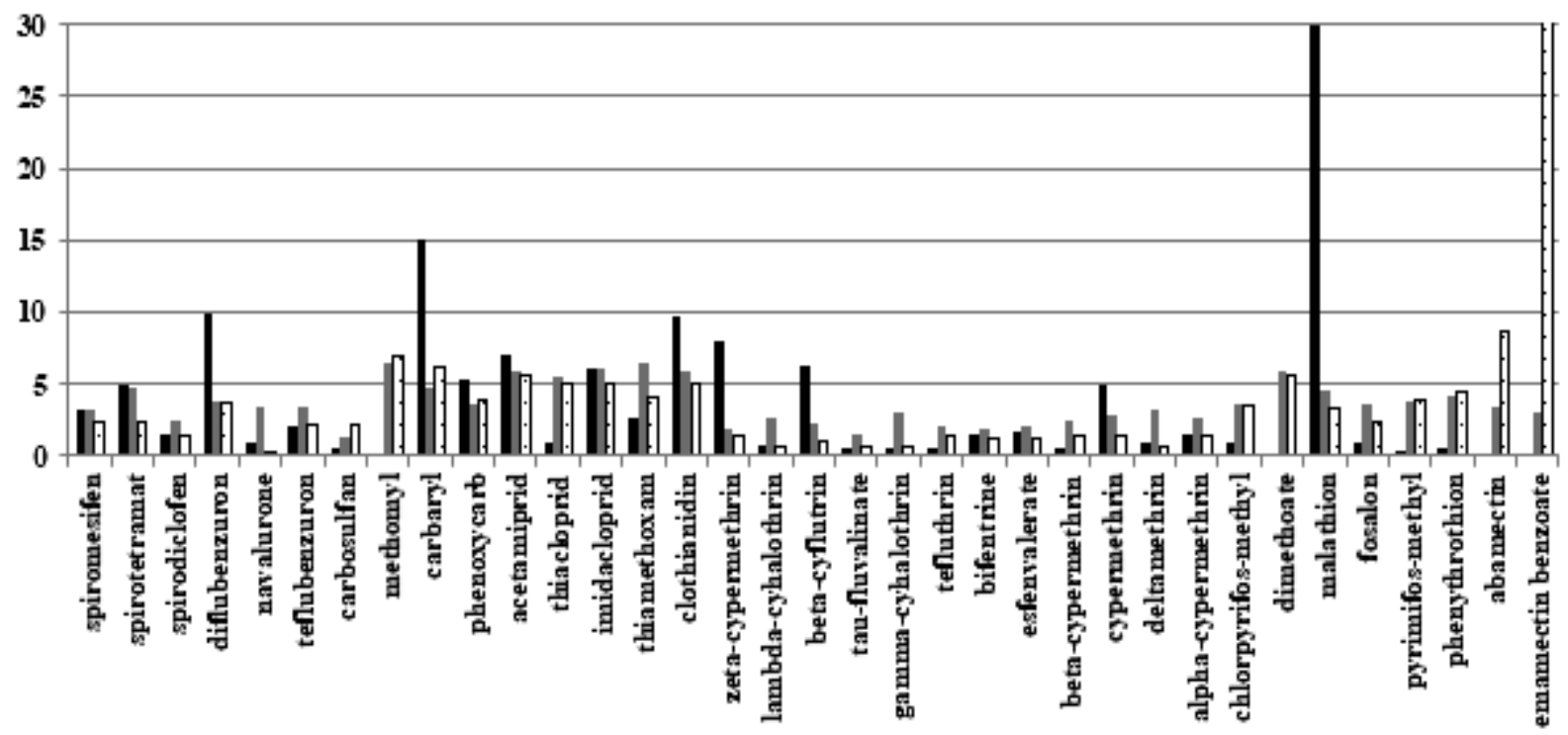

- actual indexes a indexes, calculated using linear regretion equations $\square$ indexes, calculated using nonlinear regretion equations

Fig. 1. A comparative analysis of the experimentally established $L D_{50}$ per cut (A) and $N O(A) E L(B)$ values calculated for insecticides 


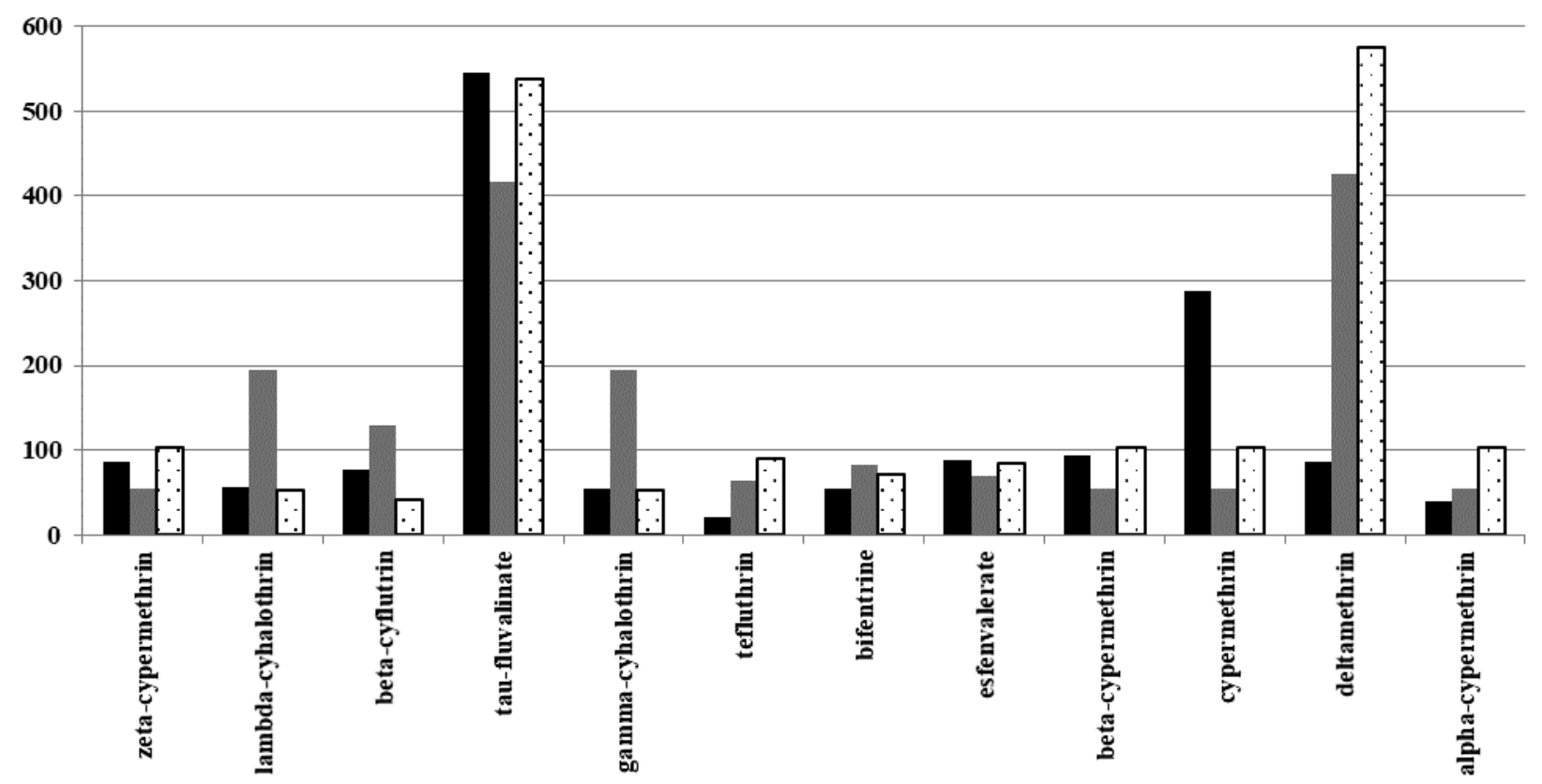

- actual indexes indexes, calculated using linear regretion equations $\square$ indexes, calculated using nonlinear regretion equations

Fig. 2. A comparative analysis of the experimentally established $\mathrm{LD}_{50}$ per os values calculated for pyrethroids class compounds

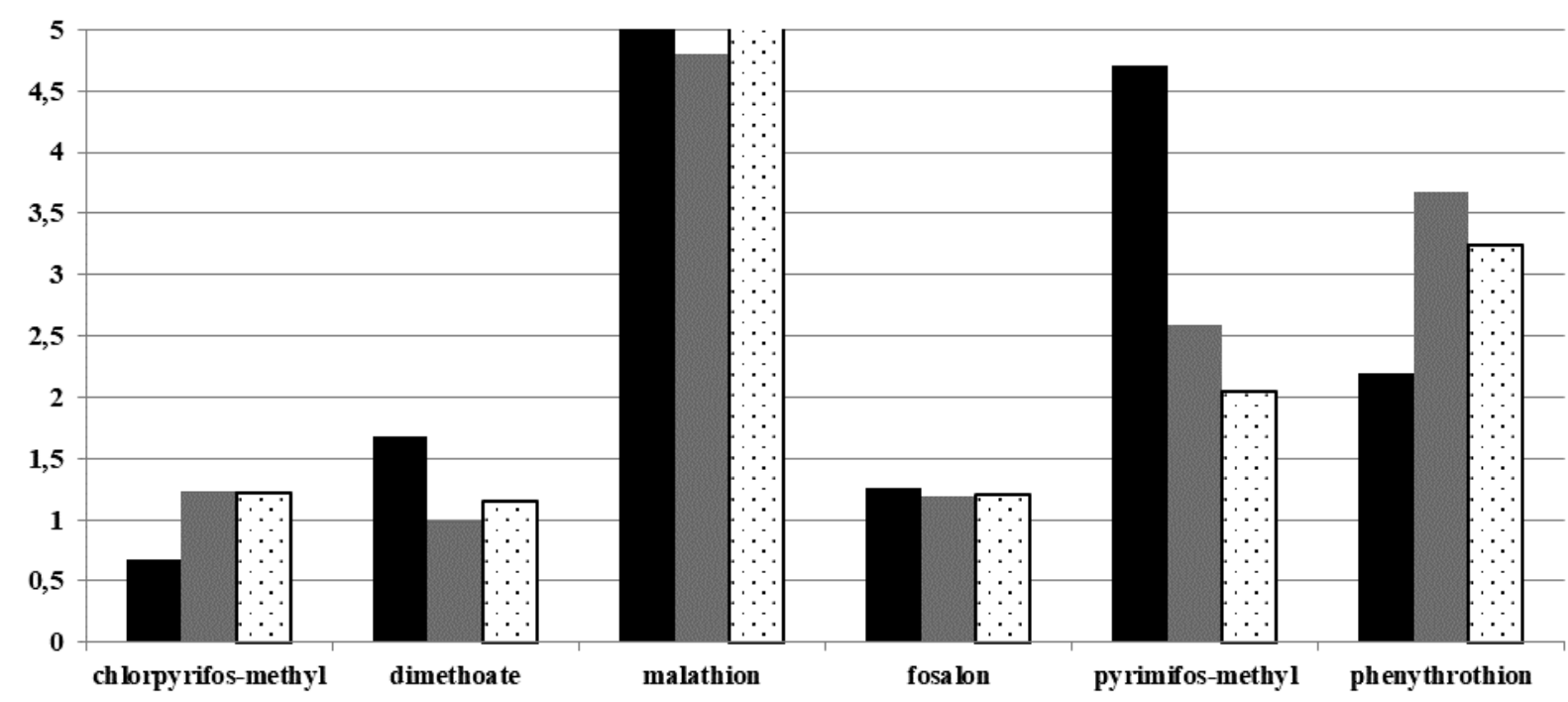

- actual indexes indexes, calculated using linear regretion equations $\square$ indexes, calculated using nonlinear regretion equations 


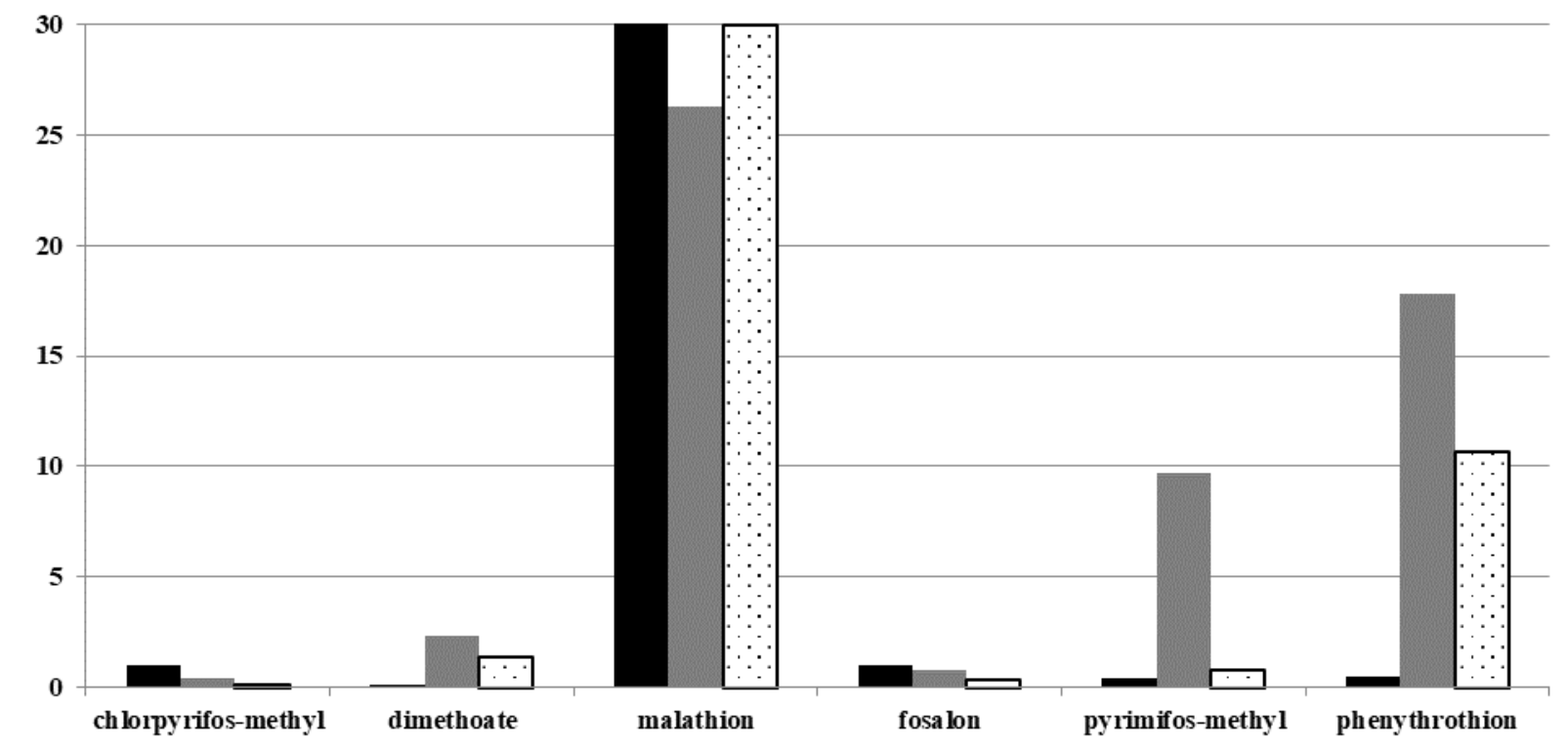

actual indexes indexes, calculated using linear regretion equations $\square$ indexes, calculated using nonlinear regretion equations

\section{B}

Fig. 3. A comparative analysis of the experimentally established $L C_{50}$ inhal (A) and NO(A)EL (B) values calculated for organophosphorus class compounds

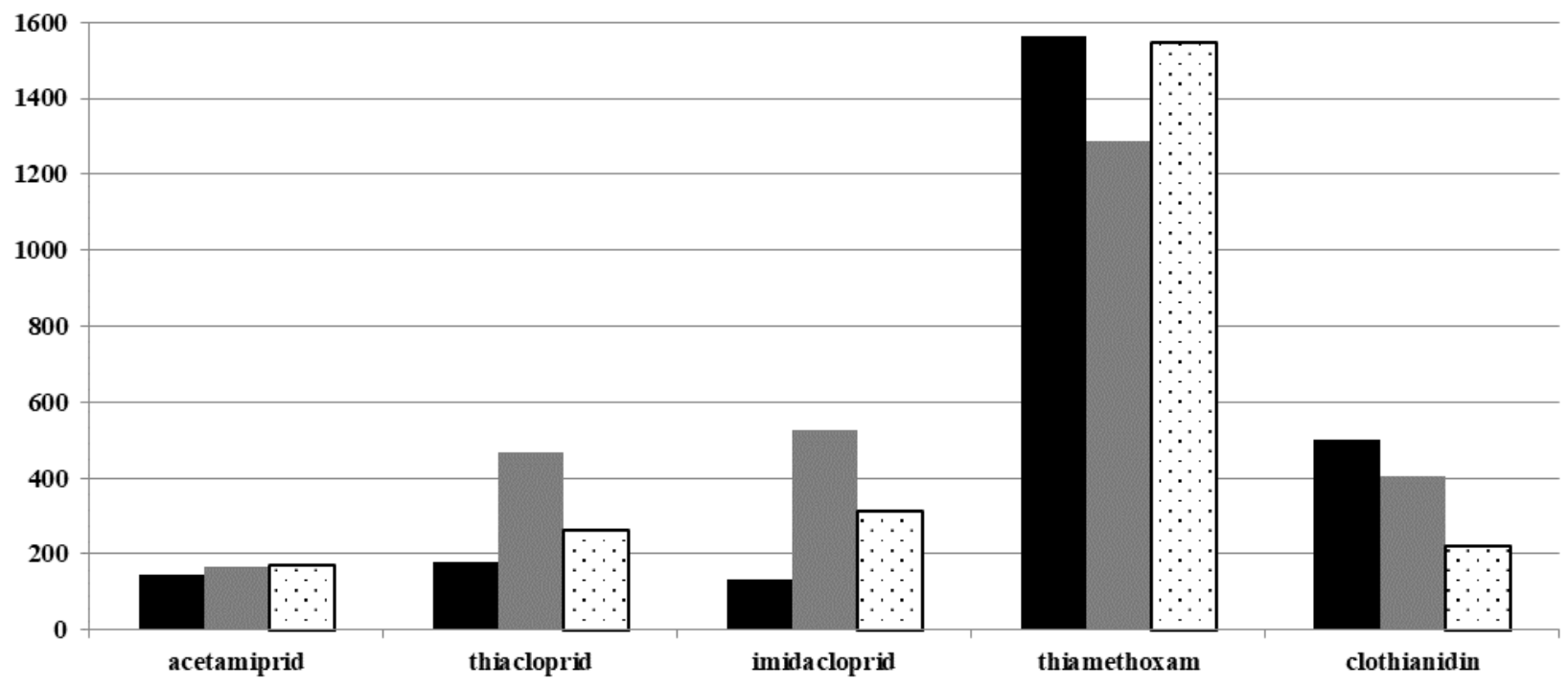

- actual indexes andexes, calculated using linear regretion equations $\square$ indexes, calculated using nonlinear regretion equations

Fig. 4. A comparative analysis of the experimentally established LD50 per os values calculated for neonicotinoid s class compounds 
The same situation (which proves the above explanations) was with methoxyacrylates fungicides (dimoxystrobin, trifloxystrobin, fluoxystrobin, picoxystrobin, kresoxim-methyl, azoxystrobin, pyraclostrobin). There was no significant relationship between their toxicological parameters and physicochemical properties. Given that for most of the active substances in this chemical class the toxicity thresholds were justified in the 1990s, often according to outdated approaches, for different species of animals (rats, mice, dogs), such an exception only confirms the established links for molecules of modern groups of fungicides.

\section{CONCLUSIONS}

1. For substantiated pairs of resultant and factorial variables for pyrethroids, neonicotinoids, and organophosphorus pesticides a reliable correlation was established (ractucal $>$ rtable at $\mathrm{p}=0.05$ ) or trend (ractucal $>$ rtable at $\mathrm{p}=0.1$ ).

2. It was indicated a good and very good consistency of the features selected for the calculations according to the Cronbach's alpha (index ranged from 0.8 and above).

3. The developed algorithm makes it possible to significantly simplify the conduction of toxicological studies of the studied classes of insecticides.

Conflict of interests. The authors declare no conflict of interest.

\section{REFERENCES}

1. Yermolova LV, Prodanchuk MG, Lep 'oshkin IV. [Development of calculation models for forecasting the risk of neonicotinoid insecticides]. Sovremennye problemy toksikologii. 2007;1:27-29. Ukrainian. Available from: http://medved.kiev.ua/web_journals/arhiv/toxicology/200 7/1_2007/str27.pdf.

2. Petri A, Sebin K. Naglyadnaya medicinskaya statistika:uchebnoe posobie. [Visual Medical Statistics: A Training Manual]. editor V.P. Leonova. Moskva: GEOTAR-Media; 2015. p. 216. Russian.

3. Anton C. Modeling and simulation for toxicity assessment. Math Biosci Eng. 2017;14(3):581-606. doi: https://doi.org/10.3934/mbe.2017034

4. Antonenko AM, Vavrinevych OP. Forecasting of triazole, amide, piperedinyle thiazol isoxazoline, oxazole fungicides hazardous effect on human health in consumption of vegetables growed in their application. Technology transfer: innovative solutions in medicine: proceedings of 2nd Annual Conference. Tallinn. 2018;25. doi: https://doi.org/10.21303/2585-663.2018.00763

5. Antonenko AM, Vavrinevych OP, Omelchuk ST, Shpak BI Hygienic substantiation of calculating models for prognosis of toxicity of different classes insecticides (first part). Медичні перспективи. 2019;24(3):106-12. doi: https://doi.org/10.26641/2307-0404.2019.3.181892
6. EU - Pesticides database: Maximum Residue Levels. [cited 2020 June 03]. Available from: http://ec.europa.eu/food/plant/pesticides/max_residue_lev els/index_en.htm.

7. Knudsen TB, Keller DA, Sander M, et al. FutureTox II: in vitro data and in silico models for predictive toxicology. Toxicological Sciences. 2015 143(2):256-67. doi: https://doi.org/10.1093/toxsci/kfu234

8. Antonenko AM, Vavrinevych OP, Korshun MM, et al. Hygienic substantiation of calculation models for toxicity prognosis of different herbicides classes. Sbornik nauchnykh trudov «Zdorove i okruzhayushchaya sreda». 2018;28:168-75. http://rspch.by/Docs/v28_sbornik.pdf.

9. Raies AB, Bajic VB. In silico toxicology: computational methods for the prediction of chemical toxicity. Wiley Interdiscip Rev. Comput. Mol. Sci. 2016;6(2):14772. doi: https://doi.org/10.1002/wcms. 1240

10. Vavrinevych OP, Antonenko AM, Korshun MM, Omelchuk ST. Hygienic substantiation of calculating models for fungicides of different classes toxicity depend on their physical and chemical properties prognosis. Environment and health. 2017;4(84):52-57. doi: https://doi.org/10.32402/dovkil2017.04.052

\section{СПИСОК ЛІТЕРАТУРИ}

1. Срмолова Л. В., Проданчук М. Г., Лепьошкін I. В. Розробка розрахункових моделей прогнозу небезпечності неонікотиноїдних інсектицидів. Совр. проблемы токсикологии. 2007. № 1. С. 27-29. http://medved.kiev.ua/web_journals/arhiv/toxicology/200 7/1_2007/str27.pdf.

2. Петри А., Сэбин К. Наглядная медицинская статистика:учеб. пособие. ред. пер. с англ.: В. П. Леонова. Москва: ГЭОТАР-Медиа, 2015. 216 с.
3. Anton C. Modeling and simulation for toxicity assessment. Math Biosci Eng. 2017. Vol. 14, No. 3. P. 581-606. DOI: https://doi.org/10.3934/mbe.2017034

4. Antonenko A. M., Vavrinevych O.P . Forecasting of triazole, amide, piperedinyle thiazol isoxazoline, oxazole fungicides hazardous effect on human health in consumption of vegetables growed in their application. Technology transfer: innovative solutions in medicine: proceedings of 
2nd Annual Conference. Tallinn. 2018. P. 2-5. DOI: https://doi.org/10.21303/2585-663.2018.00763

5. Antonenko A. M., Vavrinevych O. P., Omelchuk S. T., Shpak B. I. Hygienic substantiation of calculating models for prognosis of toxicity of different classes insecticides. Part 1. Медичні перспективи. 2019. T. 24. № 3. C. 106-112.

DOI: https://doi.org/10.26641/2307-0404.2019.3.181892

6. EU - Pesticides database: Maximum Residue Levels. URL: http://ec.europa.eu/food/plant/pesticides/max_resid ue_levels/index_en.htm. (date of access 03.06.2020).

7. FutureTox II: in vitro data and in silico models for predictive toxicology / T. B. Knudsen et al. Toxicological Sciences. 2015. Vol. 143, No. 2. P. 256267. DOI: https://doi.org/10.1093/toxsci/kfu234

8. Hygienic substantiation of calculation models for toxicity prognosis of different herbicides classes /
A. M. Antonenko et al. Сб. научных трудов «Здоровье u окружающая среда». 2018. No. 28. P. 168-175. http://rspch.by/Docs/v28_sbornik.pdf.

9. Raies A. B., Bajic V. B. In silico toxicology: computational methods for the prediction of chemical toxicity. Wiley Interdiscip Rev. Comput. Mol. Sci. 2016. Vol. 6, No. 2. P. 147-172.

DOI: https://doi.org/10.1002/wcms. 1240

10. Vavrinevych O. P., Antonenko A. M., Korshun M. M., Omelchuk S. T. Hygienic substantiation of calculating models for fungicides of different classes toxicity depend on their physical and chemical properties prognosis. Довкілля $i$ здоров'я. 2017. Vol. 84, No. 4. P. 52-57.

DOI: https://doi.org/10.32402/dovkil2017.04.052

Стаття надійшла до редакції 12.03.2020 